\title{
Media governance and corporate social responsibility of media organizations: an international comparison
}

\section{Diana Ingenhoff and A. Martina Koelling}

Department of Media and Communication Research, University of Fribourg, Fribourg, Switzerland

Media companies are increasingly becoming aware of the importance of their reputation. In order to legitimate themselves, they are starting to present themselves as 'good corporate citizens' by engaging in media governance and corporate social responsibility (CSR) activities. The communication of those activities is crucial for the building of reputation. However, to date, no comprehensive studies have been conducted to evaluate the communication of media governance and CSR activities of media organizations. This study aims to fill this gap and examined websites and reports of selected media organizations in Germany, Italy, France, Austria, and Switzerland. Results indicate that public service media organizations communicate proportionally more on media governance than private media organizations, which may be due to the fact that public service media organizations feel more accountable to the public as they have a public service obligation. Concerning the communication of their CSR activities, media organizations focus on society-oriented measures.

\section{Purpose of research and research question}

In many countries, structural changes over the past decades have led to increased journalistic and economic competition in the media industry. Consequently, large media companies in particular have become more aware of the importance of their reputation and the value of their brands (Oyedeji 2007). The public relations (PR) efforts of media organizations are becoming more professionalized and institutionalized today (Malik 2004: 170-178). They no longer merely attribute and focus public attention of others on others, but they have become aware that they themselves have to build trust and compete for public visibility in the 'attention economy' (Franck 1998, Davenport \& Beck 2001).
In order to legitimate themselves, media enterprises are therefore starting to present themselves as 'good corporate citizens'. By adopting editorial self-control mechanisms such as media governance (MG), media organizations assume journalistic responsibility. The communication of MG efforts can contribute to the building and strengthening of trustworthiness and reputation of the media organization. But given that media organizations today provide other products and services besides editorial products, they increasingly assume social responsibilities that go beyond their editorial responsibilities tied to their role as watchdog. Thus, a growing number of media companies engage in corporate social responsibility (CSR) activities and also communicate this engagement, which may have beneficial effects for their reputation and trust (Pivato et al. 2008). 
However, the conditions for public relations efforts of media organizations are not the same as for other types of organizations. The journalistic products, which may be used as vehicles for public relations messages, are edited by the media organizations themselves. By providing positive media coverage about themselves, media firms run the risk of the public identifying the media coverage as PR. This may lead to an important loss of trustworthiness (Malik 2004).

The use of other public relations channels, such as websites or corporate reports, provides media organizations with the possibility of legitimizing themselves without losing credibility. However, no systematic or comprehensive studies have been conducted to date to evaluate how media organizations communicate their CSR and governance activities.

The present study intends to fill this research gap by actively addressing the following research question: which MG and CSR activities are communicated by media organizations in different Western European countries? To answer this question, websites and reports of selected media organizations in Switzerland, Germany, Austria, France, and Italy were examined through content analysis in order to evaluate and compare the communication of their MG and CSR practices.

\section{The responsibility of media enterprises in society}

\section{Editorial responsibility and MG}

Media organizations have a societal function and thus also a social responsibility in that they are the major providers of information to citizens. They are often referred to as the fourth estate that controls the power of the executive, legislative, and judicial branches. While many authors underline this essential political function of the media in democracies, van Liedekerke (2004: 37) noted that the cultural role media organizations play in society is far more important because of their impact on societal norms and values.

To fulfill their responsibility toward society, media organizations have to comply with journalistic and editorial standards such as independence (McQuail
2005), objectivity (McQuail 2005), diversity (McQuail 1997, Napoli 1999), pluralism, and truthfulness. Media organizations also need to respect a certain degree of editorial autonomy of their newsrooms and not to abuse their exceptional position for promoting the sale of their own products or services through media coverage in their own media (crosspromotion) (Trappel \& Meier 2002).

However, media organizations are also economic players that pursue business objectives and thus focus on efficiency, profit, and market share (e.g. Owen \& Wildman 1992, Kiefer 2005: 21). Structural and technological changes over the past two decades, in particular, related to the Internet, have led to increased competition in the media sector, which has resulted in commercialization, in multiplication, and in diversification of players but also in further concentration of large media organizations (Bardoel \& d'Haenens 2004a, Meier \& Perrin 2007). These developments 'make it more difficult to balance corporate, professional, journalistic, and social interests' (Meier \& Perrin 2007: 337).

Economic pressures create new alliances and force less efficient companies out of the market. 'Media concentration provides media companies with exclusive access to the public' (Meier \& Perrin 2007: 336), which leads to a growing influence of a few but very large media organizations on economy and politics. Therefore, pluralism of opinion may be endangered, which is not prevented by the Internet either. At first glance, the Internet seems to offer so many opportunities for self-expression and pluralism, but the attention of large audiences is focused on a steadily decreasing number of well-known web portals of media organizations (Lim 2006).

The consequence of increased competition and shrinking advertising income is that economic goals gain importance and tend to replace social and editorial objectives (Blöhbaum 1994: 293-299). This has created an imbalance and growing conflict between the two main values that guide media organizations: the economic goal of profitability is becoming ever more pivotal while the media's responsibility to society and democracy is being eroded (Altmeppen 2000, Kiefer 2005).

Governmental and market mechanisms have so far been unable to restore this disturbed equilibrium. Therefore, media organizations have started to 
adopt self-control mechanisms, such as MG activities.

MG can be defined as 'a horizontal extension of government, covering not only statutory media regulation but also co-regulation' and thus underscores media organizations' own responsibility and commitment. Meier \& Trappel (2002: 71) noted that MG refers to a commitment of media organizations toward the public and different stakeholder groups; it is supposed to show that media organizations are aware of their social and political mission and that they try to reduce the risk potential of their activities. By evaluating and discussing their own power and by making editorial work more transparent, media organizations hope to legitimate their actions, to improve their economic performance, and to anticipate and avoid governmental regulations by assuming responsibility (Meier \& Trappel 2002).

MG mechanisms can be differentiated in terms of external and internal mechanisms (McQuail 2005). External MG is composed of informal mechanisms, such as market forces, lobby groups, and public opinion, but also formal mechanisms, such as the law or statutory regulation. Internal mechanisms may be differentiated into an informal dimension, which is composed of professional and ethics codes, and a formal dimension, which refers to management and self-regulation by the company or industry.

Sarcinelli (2009: 51) argued that MG not only includes the measures taken to reduce risk potentials of their activities but also the communication of those activities. Only by communicating to the public how media organizations control themselves on an editorial level is the public able to canonize malpractice (Haas \& Wallner 2007).

Media regulation structures and the influence of the government on media regulation vary nationally (Hallin \& Mancini 2004). Thus, van Cuilenburg \& McQuail (2003: 193) noted that 'the obligations laid on public service broadcasting in Europe do vary significantly from one country to another'. These typically include obligations to 'universal service, diversity of content in political, social, and cultural terms; non-profit goals of service to general public and special interest groups and minorities'. However, regulation mechanisms of print media, as well as commercial broadcasting media, also vary between countries. Because of those national differ- ences in media regulation structures, it is particularly interesting to compare how media organizations in different countries communicate their MG efforts.

There are a limited number of studies that evaluate and compare MG practice in different countries. Bardoel \& d'Haenens (2004b) give examples of media accountability practices in different European countries and in Canada. Held (2007) evaluated models of co-regulation practices of media companies of European Union (EU) member states as well as selected non-EU countries. However, there are no studies comparing how the communication of $\mathrm{MG}$ varies between countries.

\section{Media organizations and CSR activities}

Given that media organizations grow in size due to concentration processes, they not only bear social responsibility in the editorial domain, but also as corporate citizens and as employers, as the concept of CSR suggests. According to this concept, companies not only have economic and legal responsibilities, but also ethical and philanthropic ones (Carroll 1991). Economic responsibilities refer to the responsibility of selling goods and services at a profit, while legal responsibilities imply that businesses have to obey the law. Ethical responsibilities exceed the first two categories since they do not refer to responsibilities codified by law but to those which are expected by society. Discretionary responsibilities are purely voluntary, and being nonresponsive to discretionary responsibilities is not considered unethical (e.g. philanthropic contributions).

However, most authors addressing social responsibility of media companies refer to regulation mechanisms for media conduct and accountability (McQuail 1997, van Liedekerke 2004, Bardoel \& d'Haenens 2004b). CSR activities, which exceed the democratic mission of media organizations, such as assuming responsibility for employees, for the environment, or for society at large, have hardly been addressed in research so far. Von Holly \& Stark (2006) conducted a case study of the CSR activities of five German publishing companies that provides interesting insights but cannot be considered systematic either.

The present study differentiates between responsibility of media organizations toward society in terms 
Figure 1: Fields of responsibility of media organizations

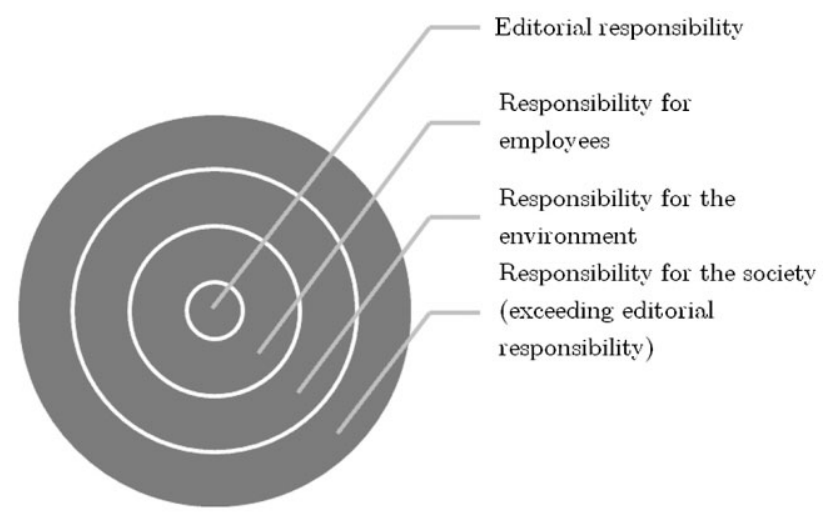

of conduct and content, which is mainly addressed by $\mathrm{MG}$ activities, and between a responsibility as a corporate citizen, which includes responsibility for employees, environment, and society at large exceeding editorial responsibility. All of the aforementioned activities are considered part of the CSR construct, however, with varying connection to the media organizations' value chain. We thus base ourselves on a distinction in CSR made by Hiss (2006) between CSR activities related and nonrelated to the organizations' value chain. The concentric circles in Figure 1 indicate how far CSR activities of media organizations are related to their value chain. Editorial responsibility is thus as a CSR engagement central to the value chain. Social responsibility for employees is tightly linked to the value chain, too, since it is the employees who have to produce content. Media organizations' responsibility for the environment can, but need not, be related to its value chain, as some of their activities may have an impact on the environment. And finally media organizations as corporate citizens also bear responsibility for society at large, which exceeds their editorial responsibilities and is thus least related to its value chain.

The communication of CSR activities can contribute significantly to the legitimating of organizations in society and thus help to preserve their license to operate.

The concept of CSR is culture-bound since it is based on norms and values. For example, Maignan (2001) noted that expectations toward CSR vary between countries. Different authors have compared CSR practices and CSR communication of compa- nies in different countries (e.g. Maignan \& Ferrell 2000, Maignan \& Ralston 2002, Matten \& Moon 2008, Welford 2005, Hartman et al. 2007, Blasco \& Zølner 2010). Also, the public's reaction toward irresponsible behavior of businesses varies between cultures (Williams \& Zinkin 2008). Differences are mainly related to cultural and institutional differences, as well as differences in the relationship between society, government, and economy (Gnyawali 1996, Chapple \& Moon 2005, Blasco \& Zølner 2010). A comparison of CSR efforts of media companies in different countries may thus reveal relevant insights.

In other fields of business, CSR activities have already become standard. However, media organizations seem to be reluctant to engage in CSR activities that exceed their social responsibility in the editorial sector (von Holly \& Stark 2006).

\section{Form of financing and their impact on MG and CSR}

The countries analyzed (Germany, Italy, France, Austria, and Switzerland) are all characterized by a dual broadcasting system that may have an impact on MG as well as CSR measures undertaken by a media organization. Whereas private media organizations are entirely dependent on income generated directly through the users of the services they provide or indirectly through advertising revenues, public media organizations obtain part of their income from public funds. Consequently, public media organizations have a public service obligation and thus have stricter regulatory requirements than private ones. A comparison of the communication of MG and CSR activities of public vs. private media organizations will provide first insights into whether public media organizations in reality communicate more on these issues.

\section{Research design and methodology}

The websites and reports ${ }^{1}$ published by media enterprises from Germany, Italy, France, Austria, and Switzerland were analyzed by means of quantitative content analysis (see Appendix A). We selected those countries because Switzerland has three main language regions and those languages correspond to 
Table 1: Media organizations included in the sample

$\begin{array}{llllllr} & \begin{array}{l}\text { Private media } \\ \text { organizations }\end{array} & \begin{array}{l}\text { SMB media } \\ \text { organizations }\end{array} & \text { Cooperative } & \text { Foundations } & \begin{array}{l}\text { Public service } \\ \text { media org. }\end{array} & \text { Total } \\ \text { Switzerland } & 7 & 1 & 0 & 1 & 1 & 10 \\ \text { Germany } & 6 & 1 & 1 & 1 & 1 & 10 \\ \text { Austria } & 7 & 1 & 0 & 0 & 1 & 9 \\ \text { France } & 7 & 1 & 0 & 1 & 1 & 10 \\ \text { Italy } & 7 & 1 & 0 & 1 & 1 & 10 \\ \text { Total } & 34 & 5 & 1 & 4 & 5 & 49\end{array}$

Table 2: Units of analysis for media governance activities included in the sample

$\begin{array}{llllllr} & \text { Website } & \begin{array}{l}\text { Annual } \\ \text { report }\end{array} & \begin{array}{l}\text { Sustainability } \\ \text { report }\end{array} & \begin{array}{l}\text { Code of } \\ \text { ethics }\end{array} & \begin{array}{l}\text { Journalistic } \\ \text { guidelines }\end{array} & \text { Total } \\ \text { Switzerland } & 20 & 11 & 1 & 0 & 2 & 34 \\ \text { Germany } & 15 & 8 & 1 & 0 & 0 & 24 \\ \text { Austria } & 11 & 1 & 0 & 0 & 0 & 12 \\ \text { France } & 11 & 6 & 1 & 0 & 0 & 18 \\ \text { Italy } & 10 & 8 & 0 & 7 & 1 & 26 \\ \text { Total } & 67 & 34 & 3 & 7 & 3 & 114\end{array}$

the languages of the adjacent countries Germany, Austria, France, and Italy. Furthermore, the countries analyzed all have a dual broadcasting system including public service and private media organizations.

The sample of the study is composed of media organizations with the biggest turnover in the respective countries that offer journalistic products as well as one public broadcasting corporation. ${ }^{2}$ To broaden the study's basis, we added to our sample of each country one small or medium-sized business (SMB), one media enterprise organized as a foundation, and one organized as a cooperative, if they existed.

Altogether, the sample contains nine Austrian, ${ }^{3}$ 10 Italian, ${ }^{4} 10$ French, ${ }^{5} 10$ German, ${ }^{6}$ and 10 Swiss $^{7}$ media organizations (see Table 1). The sample of Swiss media organizations includes media organizations from all three linguistic regions (German-, French-, and Italian-speaking).

To examine how media organizations communicate MG and CSR activities, it was determined whether such activities were mentioned on the websites and in the reports ${ }^{8}$ provided by the organizations where available.
In order to analyze the communication of $\mathrm{MG}$ activities, each website (including all subpages that carried the same URL) and report was treated as one unit of analysis (UA). The number of times $\mathrm{MG}$ activities were mentioned within the same report or website was not recorded. Altogether, 114 websites and reports were analyzed (see Table 2).

To record the extent to which media organizations reported their CSR activities, the number of articles within reports and subpages (carrying the same URL as the website) that addressed CSR activities was recorded. For communication on CSR, one article was regarded as one UA as opposed to MG activities. For MG activities, the report or website as a whole was considered a UA. This allowed us to draw a more detailed picture of the emphasis media organizations place on their CSR activities. Altogether, 862 units of analysis were found, which contained information on CSR activities. In some units of analysis, more than one aspect of CSR was addressed (society, employee, or environment). Within the 862 units of analysis, CSR activities were mentioned 880 times (see Appendix A, Table A1). 


\section{Operationalization of MG and CSR in communication}

\section{MG}

Communication on $\mathrm{MG}$ was operationalized by 11 variables (see Appendix A, Table A2), based on Haas \& Wallner (2007). The publication of journalistic guidelines refers to the publication of journalistic guidelines established by the organization itself, because only if the standards of self-regulation are known by the public can the public function as a sanctioning authority (Haas \& Wallner 2007). Information on control mechanisms provided by the organization, which assure editorial independence (e.g. ombudsmen), and on sanctions of infringements of editorial guidelines, are also considered communication on MG activities. The study further considered whether competition with other media organizations is necessary to guarantee a diversity of opinion and that editorial coverage is not influenced by private or business-related interests of third parties or journalists (editorial independence). Furthermore, communication on MG activities also includes information on the separation of ownership and editorial domains as well as on the separation of advertisers' interests and editorial domains. The study also took into account whether media organizations pointed out that their own products are not favored in their own coverage (self-/cross-promotion), whether minorities are accounted for in coverage, and whether the media organization fosters high-quality journalistic jobs. Finally, information on the involvement of recipients as an important mechanism for a functioning $\mathrm{MG}$ model was also considered information on MG.

\section{CSR}

In order to operationalize communication of CSR, this study differentiated CSR activities with respect to the publics addressed. The study distinguished between activities addressing society at large, employees of the media organization, and activities in the range of environmental protection (see Appendix A, Table A3).

CSR activities addressing society at large include health promotion (Maignan \& Ralston 2002), promotion of national culture and arts, education, financial support of social programs of third parties, free advertisement for social programs, as well as editorial support of social programs.

Other CSR activities may address employees of the media organization, such as the promotion of employees' security and well-being (Maignan \& Ralston 2002: 503), further education, programs concerning the improvement of working conditions, equal opportunities, and promotion of corporate volunteering.

CSR activities in the range of environmental protection include in-house environmental protection, environmental programs, editorial support of environmental programs of third parties, and free television advertisement for environmental programs.

\section{Results}

\section{Communication on MG activities}

Regarding the communication of $\mathrm{MG}$, results varied widely both between different aspects of MG and between countries (see Table 3). Whereas Italian $(65 \%)$ and Swiss $(26 \%)$ media organizations published a great deal of information on control mechanisms, such as ombudsmen or commissions, media organizations from other countries published hardly any at all (DE: 13\%; AT: 8\%; FR: 17\%).

Editorial independence was most often addressed by German $(50 \%)$, but much less by Swiss $(18 \%)$, Austrian (25\%), French (22\%), and Italian (19\%) media organizations. Journalistic guidelines were mainly published by media organizations from Switzerland (21\%), Germany (42\%), and Italy (19\%) and not, or hardly at all, by others. Sanctions for infringements of editorial guidelines were only mentioned in the publications and on websites of Italian $(31 \%)$ and Swiss $(6 \%)$ media organizations. The separation of advertisers' interests and the editorial domain was most often addressed by German (42\%) and Italian $(23 \%)$ media organizations but barely or not at all by the others (CH: 3\%; AT: $0 \%$; FR: $0 \%$ ).

Furthermore, competition with other media organizations and the role it plays for plurality of opinion, the separation of ownership interests and editorial domains, and self- or cross-promotion ${ }^{9}$ were barely mentioned by Swiss $(3 \%)$ and German $(17 \%)$ media organizations and not at all by others. Yet, particularly large multimedia corporations can 
Table 3: Relative number of UA addressing media governance activities by country (in \%)

\begin{tabular}{|c|c|c|c|c|c|c|}
\hline & $\begin{array}{l}\text { Switzerland } \\
(n=34)\end{array}$ & $\begin{array}{l}\text { Germany } \\
(n=24)\end{array}$ & $\begin{array}{l}\text { Austria } \\
(n=12)\end{array}$ & $\begin{array}{l}\text { France } \\
(n=18)\end{array}$ & $\begin{array}{l}\text { Italy } \\
(n=26)\end{array}$ & $\begin{array}{l}\text { Total } \\
(n=114)\end{array}$ \\
\hline Journalistic guidelines & 21 & 42 & 0 & 11 & 19 & 23 \\
\hline Control mechanisms & 26 & 13 & 8 & 17 & 65 & 129 \\
\hline Sanctions & 6 & 0 & 0 & 0 & 31 & 37 \\
\hline Competition with other media organizations & 9 & 4 & 8 & 0 & 8 & 29 \\
\hline Editorial independence & 18 & 50 & 25 & 22 & 19 & 134 \\
\hline Separation of ownership and editorial domains & 9 & 13 & 8 & 17 & 4 & 51 \\
\hline $\begin{array}{l}\text { Separation of advertisers' interests and editorial } \\
\text { domains }\end{array}$ & 3 & 42 & 0 & 6 & 23 & 74 \\
\hline Self-/cross-promotion & 3 & 17 & 0 & 0 & 0 & 20 \\
\hline Minorities & 15 & 13 & 17 & 22 & 12 & 79 \\
\hline High-quality journalistic jobs & 21 & 38 & 17 & 28 & 27 & 131 \\
\hline Involvement of recipients & 15 & 13 & 33 & 33 & 0 & 94 \\
\hline
\end{tabular}

promote or mention their products and services on other media (Trappel \& Meier 2002).

About a third or less of reports and websites of media organizations from all countries addressed the promotion of high-quality journalistic jobs and of excellent training of journalists $(\mathrm{CH}: 21 \%$; DE: 38\%; AT: 17\%; FR: 28\%; IT: 27\%). Fewer media organizations pointed out in their reports or on their websites that minorities are taken into account in editorial coverage and in how far recipients are involved in control mechanisms, for example, through sensitization for journalistic quality, product placement, guidelines, or by promoting democratic opinion-making.

\section{Communication on MG of private and public service media organizations}

Furthermore, the study examined whether communication on $\mathrm{MG}$ activities varied according to the type of media organization.

However, there are only few public service media organizations in each country so that the sample contained more private than public service media organizations and the number of UA for public service media organizations was rather small $(n=19)$, and for some countries, extremely small (Austria: $n=2$ ). Therefore, results by country are indicated as absolute values only (see Appendix A, Tables A3 and A4). To be able to compare commu- nication on MG by type of media organization, the overall results are indicated in percent. The results explained here have explorative character and need to be deepened by further analysis.

The number of UA addressing different aspects of MG was proportionally higher for public service than for private media organizations (see Table 4). It is striking that despite the small number of public service media organizations, they still provide more information on how minorities are taken into account in media coverage (see Table 4). This is most likely due to the public service obligation, which includes the promotion of minorities and cultural diversity amongst others (van Cuilenburg \& McQuail 2003). Public service media organizations proportionally provided more information on journalistic guidelines, control mechanisms, separation of advertisers' interests and editorial domains, highquality journalistic jobs, and involvement of recipients than private media organizations.

Results show that there are differences in how private and public service media organizations communicate MG.

\section{Communication on CSR activities}

Media organizations from all countries analyzed most frequently mentioned society-oriented CSR measures followed by employee-oriented CSR measures, and finally, environmental CSR activities (see Table 5). 
Table 4: Relative number of UA of private and public service media organizations addressing media governance activities (in percent)

Journalistic guidelines

Control mechanisms

Sanctions

Competition with other media organizations

Editorial independence

Separation of ownership and editorial domains

Separation of advertisers' interests and editorial domains

Self-/cross-promotion

Minorities

High-quality journalistic jobs

Involvement of recipients

$\begin{aligned} & \text { Private media } \\ & \text { organizations }\end{aligned}$
$(\boldsymbol{n}=78)$
18
29
10
6
24
10
14
3
9
21
14

Public service media organizations

( $n=19)$

37

42

11

5

26

5

26

5

42

47

32

Table 5: Communication of media organizations on their CSR activities (in \%)

$\begin{array}{lllllll} & \begin{array}{l}\text { Switzerland } \\ (\boldsymbol{n}=\mathbf{1 1 8})\end{array} & \begin{array}{l}\text { Germany } \\ (\boldsymbol{n}=\mathbf{4 4 4 )}\end{array} & \begin{array}{l}\text { Austria } \\ (\boldsymbol{n}=\mathbf{1 9 )}\end{array} & \begin{array}{l}\text { France } \\ (\boldsymbol{n}=\mathbf{1 9 8})\end{array} & \begin{array}{l}\text { Italy } \\ (\boldsymbol{n}=\mathbf{1 0 1})\end{array} & \begin{array}{l}\text { Total } \\ (\boldsymbol{n}=\mathbf{8 8 0})\end{array} \\ \text { Society } & 51 & 54 & 73 & 52 & 68 & 55 \\ \text { Employees } & 28 & 23 & 11 & 32 & 22 & 25 \\ \text { Environment } & 21 & 23 & 16 & 16 & 10 & 20\end{array}$

Table 6: Communication of private media organizations on their CSR activities

\begin{tabular}{|c|c|c|c|c|c|c|c|}
\hline & \multicolumn{6}{|c|}{ Absolute number } & \multirow{2}{*}{$\begin{array}{l}\text { Relative } \\
\text { number (in \%) } \\
\text { Total } \\
(n=594)\end{array}$} \\
\hline & $\begin{array}{l}\text { Switzerland } \\
(n=86)\end{array}$ & $\begin{array}{l}\text { Germany } \\
(n=327)\end{array}$ & $\begin{array}{l}\text { Austria } \\
(n=4)\end{array}$ & $\begin{array}{l}\text { France } \\
(n=142)\end{array}$ & $\begin{array}{l}\text { Italy } \\
(n=35)\end{array}$ & $\begin{array}{l}\text { Total } \\
(n=594)\end{array}$ & \\
\hline Society & 43 & 154 & 1 & 62 & 16 & 276 & 46 \\
\hline Employees & 23 & 89 & 1 & 54 & 15 & 182 & 31 \\
\hline Environment & 20 & 84 & 2 & 26 & 4 & 136 & 23 \\
\hline
\end{tabular}

A comparison between all five countries shows that German media organizations most frequently mentioned CSR activities on their websites (Table 5). This may possibly be related to the fact that most of the media organizations in the German sample are very large (Bertelsmann, Springer, etc.) and are therefore comparable in size with the corporate groups that so far have been analyzed in research on CSR but with no focus on media (e.g. Maignan \& Ralston 2002).
When comparing the communication of CSR activities by type of media organization, it is striking that private media organizations (see Table 6) are much more likely to report on their CSR activities than public service media organizations (see Table 7). This may be due to the fact that the latter have a public service obligation, which already provides them with a certain level of legitimization in society, whereas private media organizations are more commercially oriented and are thus more likely 
Table 7: Communication of public service media organizations on their CSR activities

\begin{tabular}{|c|c|c|c|c|c|c|c|}
\hline & \multicolumn{6}{|c|}{ Absolute number } & \multirow{2}{*}{$\begin{array}{l}\text { Relative } \\
\text { number (in \%) } \\
\text { Total } \\
(n=116)\end{array}$} \\
\hline & $\begin{array}{l}\text { Switzerland } \\
(n=26)\end{array}$ & $\begin{array}{l}\text { Germany } \\
(n=6)\end{array}$ & $\begin{array}{l}\text { Austria } \\
(n=15)\end{array}$ & $\begin{array}{l}\text { France } \\
(n=38)\end{array}$ & $\begin{array}{l}\text { Italy } \\
(n=31)\end{array}$ & $\begin{array}{l}\text { Total } \\
(n=116)\end{array}$ & \\
\hline Society & 15 & 6 & 13 & 22 & 21 & 77 & 66 \\
\hline Employees & 10 & 0 & 1 & 10 & 7 & 28 & 24 \\
\hline Environment & 1 & 0 & 1 & 6 & 3 & 11 & 9 \\
\hline
\end{tabular}

to invest in CSR activities to gain legitimization in society.

Private media organizations from Germany and France were much more likely to communicate CSR activities than their Swiss, Austrian, and Italian counterparts (see Table 6). For public service media organizations, the differences between countries were less accentuated, but scores of the French and Italian samples were slightly higher than the Swiss, German, and Austrian samples (see Table 7).

Both types of media organizations mainly communicated society-oriented CSR activities, activities addressing employees ranked second, while those addressing the environment came third. However, the quantity of communication for the three types of CSR activities is more balanced for public service media organizations.

\section{Limitations of the study}

Due to the size of the countries, the number of media organizations analyzed (particularly of private ones) varied from one country to another. Furthermore, the number of units of investigation per country, and also per type of organization, was very small (e.g. $n=19$ for public service media organizations). Comparability of the results is thus restricted.

Another limitation lies in the fact that for MG activities, only the number of websites mentioning those measures was recorded - more detailed analysis is highly desirable. For CSR activities, the analysis was more detailed as the number of articles or subpages that addressed the topic was recorded. However, a direct comparison between the communication of MG and CSR activities was therefore not possible.
Whereas the selection of private and public media organizations was conducted systematically, the selection of other types of media enterprises was not based on systematic criteria but was more exemplary.

\section{Discussion and conclusion}

Results showed that there are differences in how private and public service media organizations communicated MG and CSR activities. Public service media organizations were more likely to communicate control mechanisms in the editorial and journalistic domain. Particularly striking is that they communicated considerably more on journalistic guidelines, control mechanisms provided by the organization, on how minorities are accounted for in media coverage, how they foster high-quality journalistic jobs, and how recipients are involved as part of the control mechanisms than private media organizations. This may be related to the public service obligation of the former. Public service media organizations may feel more accountable to the public as they generate much of their income from taxation and/or fees and are also subject to stricter statutory regulations.

The study further analyzed which aspects of CSR were mostly addressed by media organizations (oriented toward society, employees, or the environment). Results show that public service media organizations from all of the countries mainly communicated CSR activities that address society in general. This could be explained by their mission; they have to focus on the general public instead of shareholders, in contrast to private media organizations. On the other hand, their potential to develop CSR activities may be limited as they spend 
taxpayers' money; this money is usually earmarked. Thus, management's liberty to develop its 'own' CSR program may be very small.

In comparison, private media organizations were considerably more likely than public service media organizations to communicate their CSR activities. These results support the assumption that the communication of CSR and MG activities might be related to the source of income of the media organization.

National differences in the communication of MG could be found, which confirms results of previous studies investigating this (Bardoel \& d'Haenens 2004b, Held 2007). This may be due to national differences in statutory media regulation (McQuail 2003, Hallin \& Mancini 2004). However, in order to explore this further, the media system and statutory regulation mechanisms themselves need to be analyzed, which could not be done in this study. The communication of CSR activities by media organizations also varies between countries. This confirms results of previous studies addressing national differences in CSR communication for other types of organizations (e.g. Maignan \& Ferrell 2000, Maignan \& Ralston 2002, Matten \& Moon 2008, Welford 2005, Hartman et al. 2007, Blasco \& Zølner 2010). However, the methodology applied in this study does not allow the determination of the reasons for this, but it seems relevant to explore this in future research.

Future research could compare governance and CSR activities of media organizations in a greater number of countries, for example, in other European countries and the United States. This would allow an analysis of whether there are differences in the approach to CSR by media organizations as already suggested by the literature on CSR activities of other types of businesses.

Furthermore, media coverage on CSR activities by media organizations should be evaluated in order to see whether and to what extent the newsrooms of the media companies themselves are exploited to communicate the media company's own PR messages.

\section{Appendix A}

\begin{tabular}{|c|c|c|c|c|c|c|}
\hline & Website & $\begin{array}{l}\text { Annual } \\
\text { report }\end{array}$ & $\begin{array}{l}\text { Sustainability } \\
\text { report }\end{array}$ & $\begin{array}{l}\text { Code of } \\
\text { ethics }\end{array}$ & $\begin{array}{l}\text { Journalistic } \\
\text { guidelines }\end{array}$ & Total \\
\hline Switzerland & 58 & 23 & 19 & 0 & 14 & 114 \\
\hline Germany & 296 & 76 & 62 & 0 & 0 & 434 \\
\hline Austria & 12 & 7 & 0 & 0 & 0 & 19 \\
\hline France & 117 & 64 & 14 & 0 & 0 & 195 \\
\hline Italy & 47 & 27 & 0 & 25 & 15 & 100 \\
\hline Total & 530 & 197 & 95 & 25 & 15 & 862 \\
\hline
\end{tabular}

Table A2: Coding scheme for measuring communication of media governance activities

Journalistic guidelines

Control mechanisms

Sanctions

Competition with other media organizations

Editorial independence

Separation of ownership and editorial domains
Publication of journalistic guidelines established by the organization itself. Only if the standards of self-regulation are know by the public, can the public function as a sanctioning authority.

Information on control mechanisms of editorial independence provided by the organization.

It is pointed out that infringements of editorial guidelines are sanctioned.

It is pointed out that competition with other media organizations is necessary to guarantee a pluralism of opinions.

It is pointed out that editorial coverage is not influenced by private or business-related interests of third parties or journalists.

It is pointed out that ownership interests and editorial domains are separated. 


\section{Table A2: Continued}

Separation of advertisers' interests and editorial domains

Self-/cross-promotion

Minorities

High-quality journalistic jobs

Involvement of recipients
It is pointed out that advertisers' interests are separated from editorial domains.

It is pointed out that own products are not favored in own coverage.

It is pointed out that minorities are accounted for in coverage.

It is pointed out the media organization fosters high-quality journalistic jobs.

The involvement of recipients is valued as an important mechanism for a

functioning media governance model.

Table A3: Coding scheme for measuring communication of CSR activities

Society

Health promotion

Cultural promotion

Education

Financial support of social programs of third parties

Free advertisement for social programs

Editorial support of social programs

Employees

Security and well-being

Further education

Working conditions

Equal opportunities

Corporate volunteering

Environment

In-house environmental protection

Environmental programs

Editorial support of environmental programs of third parties

Free TV advertisement for environmental programs
Communication of CSR activities addressing society at large, not addressed specifically to employees and excluding activities for environmental protection. Communication of health care programs, including measures for preventing and treating, which contribute to an amelioration of the physical and psychical well-being.

Communication of CSR activities promoting artistic work and culture.

Communication of activities promoting education without direct reference to the media organization. This implies the improvement of intellectual and practice oriented competences of third parties, but also activities concerning the handling of media, which encourage the participation in the opinion-forming process (e.g. media pedagogy, media use of children).

Communication of financial support of projects addressing the needy.

Communication of support of social projects by provision of free advertisement (e.g. free TV ads).

Communication of support of social projects by provision of media coverage in the editorial section of the medium.

Communication of CSR activities addressing employees of the media organization.

Communication of activities promoting employees' security and well-being.

Communication of measures adopted to assure the further education of employees as well as their sensitization for their role in the shaping of public opinion.

Communication of activities adopted concerning working conditions, which exceed statutory minimum conditions, as well as measures for an amendment of the working environment.

Communication of measures adopted to assure equal opportunities amongst employees regardless of gender, race, age or handicap.

Communication of support of employees who engage in corporate volunteering activities.

Communication of CSR activities in the range of environmental protection.

Communication of all measures adopted to reduce environmental risks caused by the media organization.

Communication of all measures adopted to protect the environment unrelated to the media organization.

Communication of support of environmental projects by provision of media coverage in the editorial section of the medium.

Communication of support of environmental protection programs by provision of free advertisement (e.g. free TV ads). 
Table A4: Number of UA of public service media organizations $(n=19)$ addressing media governance activities

\begin{tabular}{|c|c|c|c|c|c|c|c|}
\hline & \multicolumn{6}{|c|}{ Absolute number } & \multirow{2}{*}{$\begin{array}{l}\text { Relative } \\
\text { number (in \%) } \\
\text { Total } \\
(n=19)\end{array}$} \\
\hline & $\begin{array}{l}\text { Switzerland } \\
(n=7)\end{array}$ & $\begin{array}{l}\text { Germany } \\
(n=4)\end{array}$ & $\begin{array}{l}\text { Austria } \\
(n=2)\end{array}$ & $\begin{array}{l}\text { France } \\
(n=3)\end{array}$ & $\begin{array}{l}\text { Italy } \\
(n=3)\end{array}$ & $\begin{array}{l}\text { Total } \\
(n=19)\end{array}$ & \\
\hline Journalistic guidelines & 3 & 2 & 0 & 1 & 1 & 7 & 37 \\
\hline Control mechanisms & 5 & 1 & 0 & 1 & 1 & 8 & 42 \\
\hline Sanctions & 1 & 0 & 0 & 0 & 1 & 2 & 11 \\
\hline $\begin{array}{l}\text { Competition with other media } \\
\text { organizations }\end{array}$ & 1 & 0 & 0 & 0 & 0 & 1 & 5 \\
\hline Editorial independence & 1 & 2 & 0 & 1 & 1 & 5 & 26 \\
\hline $\begin{array}{l}\text { Separation of ownership and editorial } \\
\text { domains }\end{array}$ & 1 & 0 & 0 & 0 & 0 & 1 & 5 \\
\hline $\begin{array}{l}\text { Separation of advertisers' interests } \\
\text { and editorial domains }\end{array}$ & 1 & 2 & 0 & 1 & 1 & 5 & 26 \\
\hline Self-/cross-promotion & 0 & 1 & 0 & 0 & 0 & 1 & 5 \\
\hline Minorities & 4 & 1 & 1 & 1 & 1 & 8 & 42 \\
\hline High-quality journalistic jobs & 3 & 1 & 1 & 2 & 2 & 9 & 47 \\
\hline Involvement of recipients & 3 & 0 & 2 & 1 & 0 & 6 & 32 \\
\hline
\end{tabular}

Table A5: Number of UA of private media organizations $(n=78)$ addressing media governance activities

\begin{tabular}{|c|c|c|c|c|c|c|c|}
\hline & \multicolumn{6}{|c|}{ Absolute number } & \multirow{2}{*}{$\begin{array}{l}\text { Relative } \\
\text { number (in \%) } \\
\text { Total } \\
(n=78)\end{array}$} \\
\hline & $\begin{array}{l}\text { Switzerland } \\
(n=22)\end{array}$ & $\begin{array}{l}\text { Germany } \\
(n=14)\end{array}$ & $\begin{array}{l}\text { Austria } \\
(n=9)\end{array}$ & $\begin{array}{l}\text { France } \\
(n=13)\end{array}$ & $\begin{array}{l}\text { Italy } \\
(n=20)\end{array}$ & $\begin{array}{l}\text { Total } \\
(n=78)\end{array}$ & \\
\hline Journalistic guidelines & 3 & 6 & 0 & 1 & 4 & 14 & 18 \\
\hline Control mechanisms & 4 & 1 & 1 & 2 & 15 & 23 & 29 \\
\hline Sanctions & 1 & 0 & 0 & 0 & 7 & 8 & 10 \\
\hline $\begin{array}{l}\text { Competition with other media } \\
\text { organizations }\end{array}$ & 1 & 1 & 1 & 0 & 2 & 5 & 6 \\
\hline Editorial independence & 2 & 8 & 3 & 2 & 4 & 19 & 24 \\
\hline $\begin{array}{l}\text { Separation of ownership and } \\
\text { editorial domains }\end{array}$ & 1 & 2 & 1 & 3 & 1 & 8 & 10 \\
\hline $\begin{array}{l}\text { Separation of advertisers' interests } \\
\text { and editorial domains }\end{array}$ & 0 & 6 & 0 & 0 & 5 & 11 & 14 \\
\hline Self-/cross-promotion & 1 & 1 & 0 & 0 & 0 & 2 & 3 \\
\hline Minorities & 0 & 1 & 1 & 3 & 2 & 7 & 9 \\
\hline High-quality journalistic jobs & 2 & 5 & 1 & 3 & 5 & 16 & 21 \\
\hline Involvement of recipients & 2 & 3 & 2 & 4 & 0 & 11 & 14 \\
\hline
\end{tabular}

\section{Notes}

1. The reports analyzed in this study included all types of reports published on the Internet by the media organizations included in the sample such as annual reports, sustainability reports, etc.
2. If a country possessed more than one public service media organization, only one was analyzed in the sample. If all of them provided TV broadcasts (such as $A R D$ and $Z D F$ in Germany), the larger of both media organizations was chosen for analysis. If in the same country a public service media organiza- 
tion provided radio broadcasts and another one TV broadcasts, the TV media organization was chosen for analysis. If several media organizations are affiliated to a national umbrella organization, only the national media organizations (e.g. SRG SSRidéee suisse in Switzerland) was included in the sample.

3. In Austria, the seven biggest privately organized media organizations were analyzed. This was based on information from Media Watch Austria. Furthermore, the $O R F$ as a public broadcasting corporation was analyzed, as well as the TV station $A T V$, which may be classified as a SMB. There is no media enterprise organized as a cooperative nor foundation in the Austrian sample since the only one that exists (Katholische Medien Privatstiftung) does not have a website.

4. The sample of Italian media enterprises included one public broadcasting corporation, $R A I$, the foundation Mediafriends ONLUS (which belongs to the Finivest Group), the SMB Libero News, and seven private media organizations. For Italian media organizations, only the websites were analyzed as reports published by those organizations were not made available even after repeated requests.

5. In France, the seven largest media organizations were analyzed based on a list of the largest media organizations in Western Europe (Werben \& Verkaufen, http:www.wuv.de). Furthermore, the sample included France Télévision \& Radio France as a public broadcasting corporation as well as the SMB Radio France Inter and the media foundation Fondation Jean-Luc Lagardère.

6. The sample of German media organizations was composed of six of the 10 biggest media organizations according to the list provided by the Institut für Medien- und Kommunikationspolitik (http:// www.mediadb.eu), as well as one public broadcasting corporation $(A R D)$. It also included Madsack, the owner of daily papers and radio broadcasting companies, which may be considered a SMB. Furthermore, the Bertelsmann Stiftung was included as an example of a media enterprise organized as a foundation (as it owns $76.9 \%$ of the Bertelsmann group). Finally, the daily paper taz was selected as an example of a media cooperative.

7. The sample of Swiss media organizations was composed of the seven media organizations with the biggest turnover, which also included Edipresse, a media organization from the French-speaking part of Switzerland, according to a list published by the Association of the Swiss Press. Furthermore, the
Zürichsee Medien $A G(\mathrm{SMB})$, the $S R G$ as a public broadcasting corporation was analyzed; additionally, in the French-speaking part of Switzerland, the paper Le Courrier (which is organized as an association but may be treated as a cooperative as it is not profit-oriented). Furthermore, the paper Corriere del Ticino was included as the only media organization from the Italian speaking part of Switzerland.

8. The reports analyzed included annual reports, sustainability reports, codes of ethics, and journalistic guidelines.

9. In this text, 'self- and cross-promotion' refers to journalistic contributions within the editorial part of a media that refer to the media organization itself.

\section{References}

Altmeppen, K.-D. 2000. 'Funktionale Autonomie und organisationale Abhängigkeit'. In Löffelholz, M. (Ed.), Theorien des Journalismus: 225-239. Wiesbaden: Westdeutscher Verlag.

Bardoel, J. and d'Haenens, L. 2004a. 'Media meet the citizen: beyond market mechanisms and government regulations'. European Journal of Communication, 19:2, 165-194.

Bardoel, J. and d'Haenens, L. 2004b. 'Media responsibility and accountability: new conceptualizations and practices'. Communications, 29:1, 5-25.

Blasco, M. and Zølner, M. 2010. 'Corporate social responsibility in Mexico and France: exploring the role of normative institutions'. Business and Society, 49:2, 216-251.

Blöhbaum, B. 1994. Journalismus als Soziales System. Geschichte, Ausdifferenzierung und Verselbständigung. Opladen: Westdeutscher Verlag.

Carroll, A.B. 1991. 'The pyramid of corporate social responsibility: toward the moral management of organizational stakeholders'. Business Horizons, 34:July-August, 39-48.

Chapple, W. and Moon, J. 2005. 'Corporate social responsibility (CSR) in Asia: a seven-country study of CSR website reporting'. Business and Society, 44:4, 415-441.

Davenport, T.H. and Beck, J.C. 2001. The Attention Economy. Understanding the New Currency of Business. Boston, MA: Harvard Business School Press.

Franck, G. 1998. Ökonomie der Aufmerksamkeit. Ein Entwurf. München/Wien: Edition Hanser.

Gnyawali, D. 1996. 'Corporate social performance: an international perspective'. Advances in International Comparative Management, 11:251-273. 
Haas, H. and Wallner, C. 2007. 'Medienpolitik als gesellschaftliches Projekt. Die Ziele von Media Governance'. In Donges, P. (Ed.), Von der Medienpolitik zur Media Governance: 127-142. Köln: Halem Verlag.

Hallin, D.C. and Mancini, P. 2004. Comparing Media Systems: Three Models of Media and Politics. Cambridge: Cambridge University Press.

Hartman, L.P., Rubin, R.S. and Kathy, D.K. 2007. 'The communication of corporate social responsibility: United States and European Union multinational corporations'. Journal of Business Ethics, 74:4, 373-389.

Held, T. 2007. 'Co-regulation in European Union member states'. Communications, 32:3, 355-362.

Hiss, S. 2006. Warum Übernehmen Unternehmen Gesellschaftliche Verantwortung? Ein Soziologischer Erklärungsversuch. Frankfurt a. M.: Campus Verlag.

Kiefer, M.L. 2005. Medienökonomik. Einführung in einer Ökonomische Theorie der Medien. München/ Wien: Oldenburg.

Lim, J. 2006. 'A cross-lagged analysis of agenda-setting among online news media'. Journalism and Mass Communication Quarterly, 83:2, 298-312.

Maignan, I. 2001. 'Consumers' perceptions of corporate social responsibilities: a cross-cultural comparison'. Journal of Business Ethics, 30:1, 57-72.

Maignan, I. and Ferrell, O.C. 2000. 'Measuring corporate citizenship in two countries: the case of the United States and France'. Journal of Business Ethics, 23:3, 283-297.

Maignan, I. and Ralston, D.A. 2002. 'Corporate social responsibility in Europe and the US: insights from businesses' self-presentations'. Journal of International Business Studies, 33:3, 497-514.

Malik, M. 2004. Journalismusjournalismus. Wiesbaden: VS Verlag.

Matten, D. and Moon, J. 2008. "Implicit" and "explicit" CSR: a conceptual framework for a comparative understanding of corporate social responsibility'. Academy of Management Review, 33:2, 404-424.

McQuail, D. 1997. 'Accountability of media to society: principles and means'. European Journal of Coтmunication, 12:4, 511-529.

McQuail, D. 2003. Media Accountability and Freedom of Publication. Oxford: Oxford University Press.
McQuail, D. 2005. McQuail's Mass Communication Theory. London: Sage.

Meier, W.A. and Perrin, I. 2007. 'Media concentration and media governance'. Communications, 32:3, 336343.

Meier, W. and Trappel, J. 2002. 'Media Governance: Wirkungsvolles Instrument zur gesellschaftlichen Debatte von Medienkonzentration und Medienmacht?'. Medienwissenschaft Schweiz, 12:1, 66-73.

Napoli, P.M. 1999. 'Deconstructing the diversity principle'. Journal of Communication, 49:4, 7-34.

Owen, B.M. and Wildman, S.S. 1992. Video Economics. Cambridge, MA: Harvard University Press.

Oyedeji, T.A. 2007. 'The relation between the customer-based brand equity of media outlets and their media channel credibility: an exploratory study'. International Journal on Media Management, 9:3, 116-125.

Pivato, S., Misani, N. and Tencati, A. 2008. 'The impact of corporate social responsibility on consumer trust: the case of organic food'. Business Ethics: A European Review, 17:1, 3-13.

Sarcinelli, U. 2009. Politische Kommunikation in Deutschland. Wiesbaden: VS Verlag.

Trappel, J. and Meier, W.A. 2002. 'Gesellschaftliche Folgen der Medienkonzentration aus medienökonomischer und publizistikwissenschaftlicher Perspektive'. Medienwissenschaft Schweiz, 12:1, 56-65.

van Cuilenburg, J. and McQuail, D. 2003. 'Media policy paradigm shifts: towards a new communications policy paradigm'. European Journal of Communication, 18:2, 181-207.

van Liedekerke, L. 2004. 'Media ethics: from corporate governance to governance, to corporate social responsibility'. Communications, 29:1, 27-42.

von Holly, I. and Stark, B. 2006. 'Gesellschaftliches Engagement deutscher Medienverlage. CSR Strategien auf dem Prüfstand'. Prmagazin, 37:12, 61-68.

Welford, R. 2005. 'Corporate social responsibility in Europe, North America and Asia. 2004 survey results'. Journal of Corporate Citizenship, 17:1, 33-52.

Williams, G. and Zinkin, J. 2008. 'The effect of culture on consumers' willingness to punish irresponsible corporate behaviour: applying Hofstede's typology to the punishment aspect of corporate social responsibility'. Business Ethics: A European Review, 17:2, 210-226. 